\title{
Hybrid leadership councils: envisioning inclusive and resilient governance
}

\author{
Alice Ba ${ }^{1}$, Kara Ellerby ${ }^{1}$, Daniel Green ${ }^{1}$, Daniel Kinderman', Stuart Kauffman ${ }^{1}$, Matthew Weinert ${ }^{1}$ and \\ Saleem H. Ali ${ }^{1,2,3^{*}}$ (D)
}

\begin{abstract}
To address future challenges of planetary decision-making on key ecological and social issues in an increasingly nationalistic world, we propose a new global governance model of technocratic ascendancy that can be integrated with quasi-democratic norms. Our model proposes the creation of a series of self-organized "Hybrid Leadership Assemblies" (HLA) led by "Hybrid Leadership Councils (HLC)" and supported by a number of more specialized Issue Action Committees (IACs) in five key issue areas: Environmental Protection and Climate Change Management, Security from Armed Conflict, Fighting Poverty and Inequality, Managing Population Growth, and Women's Inclusion. Inspired by the popular environmental slogan, "Think global, act local," our proposed governance model makes a revived subsidiarity principle central to its re-imagination of global governance as a non-hierarchical system of organization. In addition to creating opportunities to approach challenges at multiple levels of governance, our broadly participative model also makes innovative networking across different groups, levels of governance, and issues integral to solving complex socio-ecological problems.
\end{abstract}

Keywords: Global governance, Subsidiarity, Leadership, United Nations, Hybridity, Sustainability

\section{Introduction}

While the final 1995 report of the Commission on Global Governance, Our Global Neighborhood, defined global governance as "the sum of many ways individuals and institutions, public and private, manage their common affairs," contemporary structures and processes of global governance overtly privilege state decision-making within international organizations or intergovernmental networks. Because of this state-centric focus, global governance tends toward a system in which national interests outweigh planetary ones, managerial practices and economic modes of governance inculcate shortterm logics and practices of profit over long-term amelioration of and solutions to persistent problems, and increasing reliance on rule by elites marginalizes local communities. In this paper, we propose that future global governance models require a hybrid leadership approach to gaining traction in world affairs. The future

\footnotetext{
* Correspondence: saleem@udel.edu

'Department of Political Science, University of Delaware, Newark, DE 19716, USA

2Department of Geography, University of Delaware, Newark, DE 19716, USA Full list of author information is available at the end of the article
}

we envisage considers traditional forms of hierarchical institutions built on established loci of trust and a polycentric approach to managing nationalism. The literature in Futures Research has thus far neglected ways of improving environmental governance through a negotiation of hierarchical social norms. Instead of following a revolutionary approach that attempts to completely subvert the existing system, we propose a pragmatically hybrid approach that respects and builds on established institutions.

Attempts at bringing multiple stakeholders into the conversation have focused on knowledge- sharing through scientific panels (such as the IPCC, IPBES, and IRP) or broad discussion and networking forums such as the annual Davos meeting and the World Economic Forum's existing Global Future Councils. Critics of both these approaches note that there is still a fundamental disconnect between knowledge generation and policy implementation. The existing system is highly inefficient and the time lag caused by tiers of consensus building at conferences makes many policies obsolete by the time they are ready to be implemented. Important initiatives can be stymied for long periods by a few veto players. 
To address these problems, we propose a nimble governance model offering meritocratic leadership that respects state sovereignty but also empowers expertise through a quasi-democratic process of accountability and enforcement authority.

While academics and practitioners have identified a range of deficiencies and inefficiencies in the global governance framework, our model foregrounds, and responds to, four of these features:

A. Democratic deficiencies. Notwithstanding international treaties and normative instruments which address the rights of indigenous peoples, minority, ethnic and religious groups, women, and others, many still remain excluded or marginalized in domestic structures of governance and in global institutions and deliberations. Further, while civil society organizations and the private sector are increasingly viewed as stakeholders in global governance initiatives, they need to be empowered as drivers of change and providers of solutions, and more formally and robustly incorporated into the architecture of global governance.

B. Cognitive deficiencies. The framing of state and international organization policies and programs in terms of short-term benefits and political expediency inhibits efforts to tackle persistent problems. A realistic, not idealist, global (sometimes labeled planetary or cosmopolitan) mindset needs to be cultivated. In the post-Cold War era, concepts such as human security and sustainable development, despite their shortcomings, exhibit new ways of thinking that should compel policymakers to shift focus to longer-term solutions to persistent problems. Additionally, consensus on the definition, nature, and scope of global issues and problems remains largely assumed-and primarily Western or Northern in orientation.

C. Deficiencies in leadership and implementation. Problems too often languish without receiving adequate attention from the international community. This situation has only been exacerbated in recent years, by the rise of emerging powers with very different interests and "sovereigntist" inclinations [33, 35], by institutional designs which facilitate gridlock [22, 37], and by the declining interest of the USA in global leadership, replaced by a shift to unilateralism and minilateralism [15]. While concluding international conventions and cultivating normative consensus remain primary in global governing, too often they mask weak political wills to comply with, and enforce, agreements.

D. Resource deficiencies. Resource deficiencies, inefficiencies, and inequalities have resulted in environmental damage, corruption, poverty, and short-term profits taking priority over long-term sustainable growth. Too few resources are devoted towards sustainable development, including addressing global problems such as climate change, environmental degradation, and poverty. In sum, while economies are efficient in generating profits, they are inefficient in satisfying human needs, and resources are inequitably distributed. The current wave of global populism can be seen at least in part as a response to these problems.

\section{Proposed governance model: hybrid leadership councils \\ Overview of hybrid leadership councils}

We believe the way around these deficiencies is the creation of a series of self-organized "Hybrid Leadership Assemblies" (HLA) led by "Hybrid Leadership Councils (HLC)." These Assemblies and Councils would consist of those states, international organizations, relevant UN agencies, businesses, NGOs, and other transnational organizations that collectively have the motivation and resources to push forward global problem-solving initiatives in a particular issue area. Our model builds upon a phenomenon within the UN system in which states (usually middle powers) adopt, fund, and nurture specific projects. For example, Japan, Canada, and Norway have been active in the promoting the human security agenda; the UK, Sweden, and Spain have been the largest donors to the UN's peacebuilding fund; and the Netherlands has been a staunch advocate and funder of development initiatives, etc. We also build on new modes of hybrid governance in the EU, which bring together government, business, and civil society (for example within Europe's 2020 Strategy), as well as "experimentalist governance" [32, 40]. Along these lines, one HLC would maintain global momentum to ameliorate climate change and environmental degradation, for example, while another would focus on problems of population growth. Those active in multinational diplomacy around these issues know each other and know who the most motivated, engaged, and effective contributors to solutions are. We envision that a broad group of such actors in each issue area would come together, forming an HLA to select an HLC that will lead global collaborative efforts that area.

The logic of this approach is that some participants (such as middle-power states) would provide political leadership and diplomatic impetus; others (e.g., corporations and private foundations) would contribute resources; 
NGOs would muster popular support and promote volunteerism; and still others (e.g., UN agencies) would provide the institutional structure to coordinate and organize diplomatic and political processes of building consensus on action and then implement the agreed-upon action. All could contribute relevant expertise. Given the limited "bandwidth" of even very large organizations, it is likely that participating bodies will take a leadership role in only one HLC, so they can focus their efforts on that issue-area.

\section{Rationale for hybrid leadership councils}

In the Aristotelian view, politics entails decision-making for the collective good or public interest. Politics thus occurs in the space "in between" individuals, and hence is not reducible to their private interests: it is a relational, not an atomistic or egoistic project. Institutions serve to moderate and mitigate competing visions of the public good and ensure that activity is designed to promote the flourishing of human living. Our model of global governance revives this conception of politics in an expanded form, adding to Aristotle's notion the insights that the public and private spheres are inextricably intertwined, as are economics and politics.

In constructing a new model of global governance, we believe we must begin with what exists, and especially with what works. The modern social democratic nation-state, the global free market system, and the constellation of international governmental organizations centered around the United Nations have together created a world that is freer, more peaceful, and more prosperous than ever before in human history. Within the UN system, a broad set of models have been developed to address specific problems in issue-areas such as economic development, women's rights/human rights, and environmental protection. Many of the most important initiatives have been propelled by a series of regional and global conferences culminating in the signing of a multilateral treaty or convention. We propose to build on these practices and institutions, not to replace them.

At the level of global governance-that is, putting aside deficiencies of national and local government in many areas-we focus on addressing the democratic, cognitive, leadership, and resource deficiencies discussed above. On the one hand, major initiatives to address global problems must typically wait until some degree of political and cognitive consensus emerges among the leading great powers. On the other hand, once begun, these initiatives tend to languish with inadequate resources for implementation, even when they prove themselves extremely effective, while others lack democratic accountability. Our proposed system of hybrid leadership councils and assemblies could address these problems.

\section{Examples of existing hybrid institutions}

There are many existing models of effective hybrid institutions currently operating today. The International Labor Organization (ILO), for example, combines government, worker, and employer representatives. The International Union for the Conservation of Nature (IUCN) is composed of 1300 governments and civil society organizations and actively seeks the input of 16,000 experts on issues related to diverse aspects of the environment. The Global Environmental Facility (GEF) was established in 1992 as a unique partnership of 18 UN agencies, multilateral development banks, national entities, and international NGOs to address environmental challenges, fund environmentally sustainable initiatives, and support "multi-stakeholder alliances to preserve threatened ecosystems." The Interparliamentary Union (IPU) combines 173 member state parliaments and the parliaments of 11 regional organizations. Other bodies, such as the Economic and Social Council (ECOSOC) within the UN system, include a formalized procedure for incorporating nongovernmental organizations into its structure and processes. Still, others, e.g., the UN's Global Compact, seek to harness the voluntary commitment of multiple stakeholders (at present 9388 companies but also, since its 2005 refinement, 162 governments, Local Networks Advisory Groups, academic experts, and civil society) to promote universal principles related to advancing human rights, labor standards, environmental protection, and good governance/anti-corruption.

Other examples of hybrid governance are more transnational than international. Thus, a range of "experimental, sub-national and transnational arrangements" has emerged in environmental governance to respond to perceived governance gaps created, at least in part by the challenges associated with "megamultilateral" initiatives [17]. One of them, the Climate Alliance, today includes participation from 1700 member municipalities and districts covering 26 European countries, and a variety of regional governments, NGOs, and other organizations, and is supported by a European Secretariat and National Coordination Offices in support of promoting climate action both in European municipalities and with the indigenous peoples of the Amazon River basin. The Renewable Energy and Efficiency Partnership partners with 45 state governments and over 300 other entities in support of clean energy practices and is governed by a transnational board comprised of governmental, inter-governmental, industry, and societal leaders. Finally, the C40 comprised of the world's largest cities and the recently formed US Climate Alliance similarly illustrate the potential for global cooperation including sub-national units.

There are also more region-specific examples of hybrid cooperative frameworks, such as the Great Green Wall 
and Farmer Managed Natural Regeneration programs discussed below. In Southeast Asia, "collectives of varied actors" doing important governance work include the Roundtable on Sustainable Palm Oil, a not-for-profit, voluntary association of corporate and civil society actors and now "the premier sustainability certification scheme for the palm oil sector" [7, 24]. Additionally, there is the tripartite Extractive Industries Transparency Initiative that brings together states, corporations, and civil society/NGOs as formally equal partners in support of enhanced transparency in the mining sector. Still, another example is to be found in the Cooperative Mechanism of the Straits of Malacca and Singapore, which offers a distinct model of cooperation and partnership between varied actors with varied responsibilities (the International Maritime Organization, the Straits' littoral states, and private (industry) and public (state) users of the Straits). In this instance, private and semi-private foundations have also played critical roles in creating a hybrid governance model based on both inter-state collaborations and public-private partnerships [4]. While limited in some critical ways, such regional efforts nevertheless offer good examples of existing hybrid institutions in operation.

\section{Organizational design and areas of responsibility for HLCs} (see Fig. 1)

Our model deepens reliance on such innovative networking by calling for the creation of a single Hybrid
Leadership Council (HLC) and Hybrid Leadership Assembly (HLA) in each of five key issue areas: Environmental Protection and Climate Change Management, Security from Armed Conflict, Fighting Poverty and Inequality, Managing Population Growth, and Women's Inclusion. Each HLC would function as an elected leadership body for a self-organized coalition of states, international governmental organizations (IGOs), businesses, non-governmental and charitable organizations (NGOs), and specially formed new bodies committed to addressing the specific set of global challenges that is the focus of their HLC, based on a set of basic guiding principles.

Each HLC would be constituted at a Hybrid Leadership Assembly meeting to which representatives of all organizations committed to addressing the global problems in the identified issue area would be invited. Each Assembly would be divided into four sectoral groups: states; businesses and business coalitions; IGOs; and NGOs. The participating organizations in each sector would nominate a fixed number (perhaps four) of their number to take a leading role by serving on the Hybrid Leadership Council itself. The Assembly as a whole would then vote to confirm or reject each sectoral nominee by majority vote, with each sector commanding one quarter of all votes.

All HLC members would be expected to be committed to take the lead in providing direction, resources, and expertise to addressing their issue area. The states on

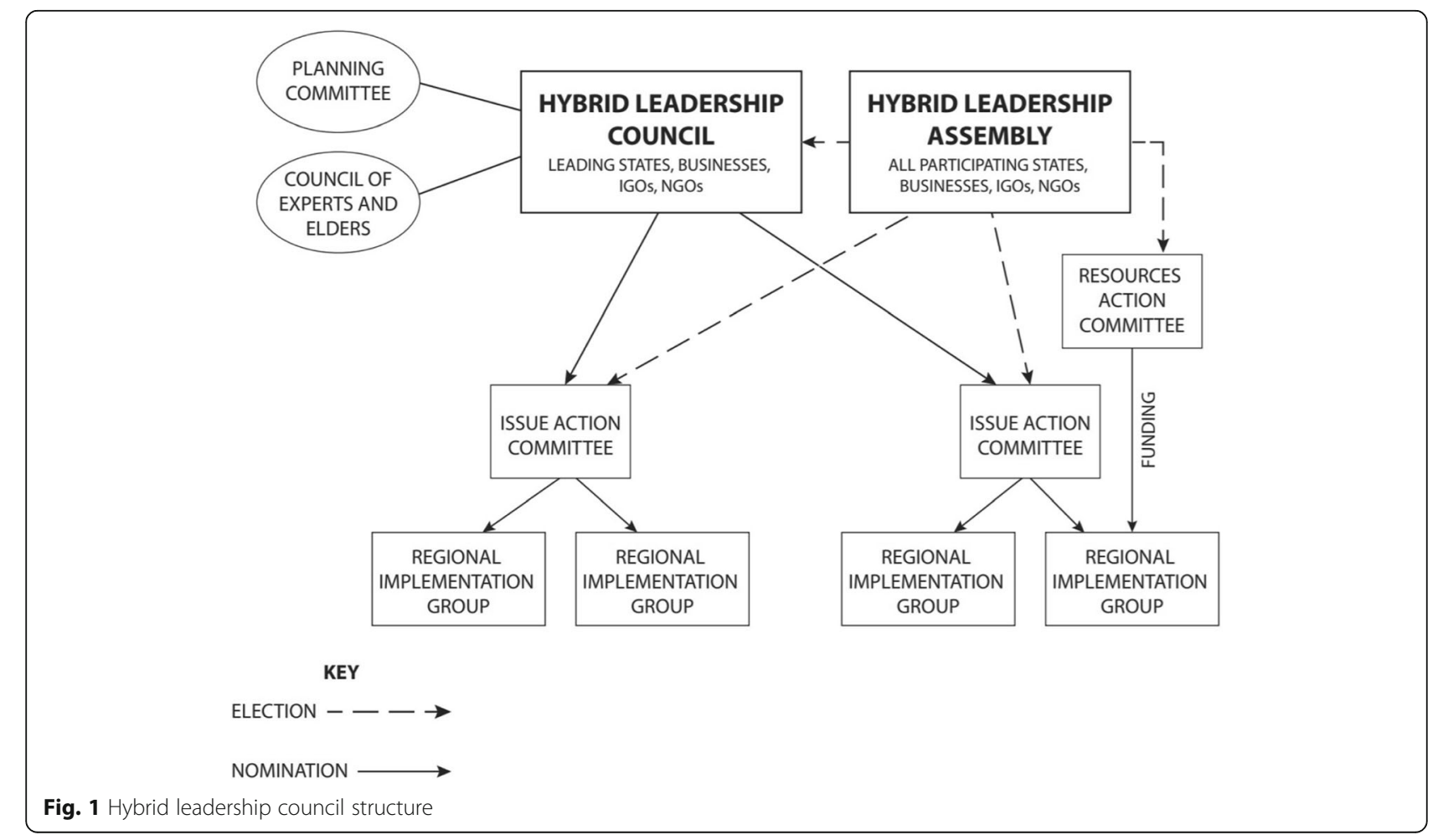


each HLC would preferably be middle powers, willing to make their HLC and its issue area a particular focus of their foreign policy energy. We expect that states, working with and through IGOs, would take the lead in organizing and recruiting members for the HLC Assembly. The businesses in question would generally be multinational corporations or business associations prepared to commit significant resources to the effort. The IGOs would be those focused on the issue area, many of them members of the UN system. The NGOs, finally, would ideally be of diverse kinds, including volunteer issue-oriented groups, charitable groups, and others.

The role of the HLCs will be to oversee the creation of overall plans, policies, and priorities for the group through a process of broad consultation. Each HLC would establish a small standing Planning Committee charged with drawing up these plans, supported by the full range of expertise commanded by HLC members. They would also each establish an Advisory Council consisting of respected members of communities in which HLC efforts will be carried out, as well as scientific and technical experts on the problems they will be addressing and state-of-the-art practices in addressing them. Willingness to contribute substantial funds to joint efforts should be a firm expectation of all states and businesses that join the Assembly, and especially those on the HLC itself. Our hope is that the effectiveness of HLC coordinating efforts would encourage states, IGOs, and NGOs to devote a major and ultimately predominant proportion of available resources that they have earmarked to address the HLC's issue.

We envision that the HLCs and Planning Committees would produce relatively general plans, establishing HLC priorities. These would be subject to amendment by subsequent meetings of the relevant Assembly, which should occur every few (3-5) years. New elections for the HLC would also be held at each Assembly meeting. To translate HLC plans into action, each Assembly will also elect a set of Issue Action Committees (IACs) based on plans generated by the HLC; there would be one IAC for each specific issue on which the HLC plans a major initiative. For example, the HLC on Environmental Protection and Climate Change management might propose Issue Action Committees (IACs) on fighting climate change, reducing water pollution, and so on. The IACs would be composed of members of the Assembly-replicating the HLC's four-part mix of states, IGOs, NGOs, and businesses-and would usually not include members of the HLC itself. They would be elected according to the same procedure used to elect HLC members. Each IAC would design specific policy initiatives within its area. For example, the IAC on air pollution might design a program for replacing coal-fired power plants with renewable facilities generating renewable energy. The IACs would draw on the resources of the HLC's Advisory Council in optimizing their programs based on global best practices. Finally, alongside the IACs, each Assembly would elect a similarly hybrid Resource Action Committee charged with acquiring and coordinating funding for the IACs' projects.

To implement these programs, the IACs, in consultation with relevant Assembly members and others, would create Regional Implementation Groups (RIGs). These RIGs would be designed to connect IAC members with local partners that would actually carry out the programs. For example, the HLA on Managing Population Growth might establish an IAC focusing on promoting family planning and improving the availability of contraception; the IAC might then create a RIG for southern Africa linking representatives of global actors on the IAC such as the United Nations Population Fund with providers of women's health services in the countries of southern Africa. The RIGs would be advised by regional Advisory Councils who would assist in tailoring IAC plans to take into account the needs of the countries and communities in which the programs would be implemented.

\section{Managing today's global problems: HLCs in practice \\ Hybrid leadership council on climate change and environmental protection}

Arguably the most pressing issue facing Planet Earth today is accelerating global warming and climate change. The global response has not been commensurate, however, confronting challenges at all levels of governance. At the level of the international community and in individual states, tensions between environmental and economic priorities hamper negotiation of global environmental accords and constrain environmental regulatory efforts: self-interested economic concerns often win out over the needs of the global environment. At the most local level, community groups interested in protecting local economies or traditional ways of life against national and/or corporate agendas can be alternately obstacles to and forces for change. Given the transnational character of environmental challenges and the range of interlocking issues and interests involved, we believe that hybridity and creative collaborations are especially important in generating effective action in this issue area.

An environmental HLC, with support from different Issue Action Groups, can provide critical leadership, building upon examples of hybridity already at work. Two such examples-Great Green Wall for the Sahara and the Sahel Initiative (GGW) and Farmer Managed Natural Regeneration (FMNR) - are found on the African continent, where climate change and unsustainable land management have produced a growing crisis of desertification and famine, as well as heightened risk of disease, 
natural disasters, and species extinction. "[A projected] 7,700-kilometer wall of trees" across 11 countries, the GGW aims "to restore 50 million hectares of land, provide food security for 20 million people, create 350,000 jobs, and sequester 250 million tons of carbon" [12, 23]. Especially notable is the GGW's multi-scale approach to governance and the effects of climate change and desertification. In addition to the pan-African convention that provides its genesis and the initiative displayed by the African Union, the GGW also enjoys support from "a mosaic" of inter-governmental, global-transnational, and (sub- and pan-) regional actors, 10 other participating governments from Europe and Africa beyond the 11 directly affected [12], and critical engagement of local communities able to make local adaptations in implementation [25].

In the case of FMNR, NGO-mediated farming programs have worked with regional agricultural research centers, local community organizations, the World Bank, and the UN's International Fund for Agricultural Development (IFAD) to build a transnational network of governmental, non-governmental, and local stakeholders [34]. Similar efforts are also being promoted in parts of Southeast Asia. As with the GGW, the FMNR initiatives critically include local actors, which, in this case, identify, reclaim, and regenerate indigenous species of vegetation that had been previously cut to make way for either non-native plants or other purposes $[9,14]$. Offering a "low-cost, replicable" technique that "provides direct benefits within a short time", FMNR also has potential for further development under the Partnerships for SDGs platform managed by the Division for Sustainable Development of the United Nations Department of Economic and Social Affairs (DSD/DESA).

While not without their criticisms, these efforts offer notable examples of the kind of impactful hybrid leadership and hybrid collaborative models this proposal envisions and sees as promising paths forward. These models also demonstrate the necessary initiative exercised by well-positioned actors in connecting material, personal, and technical resources with local interests and agency, convening actors and interests, and assuring community ownership and adaptive capacities integral to any effort to address the world's many environmental challenges.

We envision an environmental HLC playing a similar role. Indeed, GGW might be seen as an example of the kind of IACs that could be created to address other environmental problems, such as climate change, (non-greenhouse) air pollution, and oceanic pollution. The HLC could also provide sustained leadership in linking what may be otherwise fragmented or disconnected efforts, and in so doing, build upon existing best practices.
Hybrid leadership council on security from armed conflict Since World War II, the vast majority of armed conflicts have taken the form of civil wars [28]. Genocides and politicides such as those in Rwanda and Cambodia have taken place in the context of such civil wars [29]. Most of these conflicts, especially the most violent ones, have been ethnic or identity-based conflicts, with most of the rest fueled primarily by ideology or efforts to control resources [20]. Other sources of mass political violence include deadly ethnic riots and government repression $[18,31]$.

In contrast to this continuing problem of violence internal to states, international wars have become extremely rare. Their near-disappearance has been fostered by an international society built around the United Nations system and based upon the principle of mutual respect for state sovereignty and territorial integrity. International efforts to address civil wars have been common but have had mixed success at best. Experts remain at odds about the how governments can be structured to prevent the outbreak of ethnic civil wars [38]. The primary international tool for settling ongoing civil wars, mediation, is frequently attempted but fails more often than it succeeds [6]. Finally, efforts at peacekeeping and peacebuilding are badly weakened by systemic problems built into UN peacebuilding efforts, such as the neglect of the local sources of violent outbreaks and the premature introduction of conflict-generating liberalization measures in post-conflict political and economic systems [3, 27].

In this context, a Hybrid Leadership Council on mass political violence could help, but it would have to concede a primary role to existing institutions for most purposes. Great-power states and the United Nations Security Council have been the primary actors in working to prevent international war, and they are the only actors able to prevent or stop the internationalization-and thus escalation-of civil wars. An HLC could do little more in these areas than to encourage continued observance of peace-strengthening international norms. The same is true for efforts to prevent and reverse the proliferation of weapons of mass destruction: great-power and UNSC leadership is irreplaceable for these efforts.

An HLC could, however, make important contributions in the areas of peacemaking (mediation) and post-conflict peacebuilding. On the first point, mediation to achieve peace settlements is now conducted by a rotating cast of state actors, NGOs, and IGOs [5]. An HLC could be helpful in coordinating mediation efforts to reduce the problem of belligerent "forum shopping" among competing potential mediators. Second, post-conflict reconstruction has also been shown to be amenable to hybrid and coalitional arrangements: peacebuilding in Kosovo, for example, featured cooperation between the United Nations, NATO, and the OSCE, as well as interested states and NGOs. A standing HLC on peacebuilding could 
work to routinize such cooperative efforts. At the same time, by serving as an institutional memory for hybrid peacebuilding efforts, an HLC could contribute to the implementation of best practices in peacebuilding that are currently ignored by the UN and other large existing bureaucracies.

An HLC on armed conflict could also be a site for the development of new models for the management and resolution of potential armed conflicts. For example, the use of popular plebiscites for managing ethnic or nationalist separatism is already beginning to spread, as in the cases of Quebec, Scotland, and Catalonia. Such referenda or plebiscites could be made fairer and more palatable to states if internal borders were questioned at the same time as external ones. If, for example, Scotland were to vote for independence, the same principle of self-determination suggests that those localities within it which prefer to remain in the UK should be permitted to do so. If pro-secessionist parts of Scotland lacked the territorial integrity to form a viable state, that fact might dissuade the secessionists from proceeding. Plebiscites in current "frozen conflicts" such as in Georgia and Azerbaijan would have to allow voting by refugees (including IDPs) from those conflicts, whose votes would be counted in the tallies of the localities from which they originally fled. Either the UN or regional organizations such as OSCE or the AU would be the most likely institutions to oversee such plebiscites.

\section{Hybrid leadership council on poverty and inequality}

In 2015, United Nations member states agreed on an overarching agenda comprised of 17 goals, disaggregated into 169 mostly measurable targets, to replace the expired Millennium Development Goals (MDGs). These Sustainable Development Goals (SDGs) aim to mobilize efforts by multiple actors at all levels to end poverty, protect the planet, and ensure prosperity for all.

While the SDGs have marshaled inter-agency cooperation and coordination within the UN system, their execution relies on national frameworks of ownership, not legally binding obligations. Further, there is no single agency or set of agencies charged with coordinating the activities of all actors towards achieving the goals. Our proposed hybrid leadership council on poverty and inequality offers the added value of providing an administrative, structured mechanism for assembling all relevant stakeholders towards the coordination of best practices, strategies, and tactics for meeting their obligations under the SDG framework, and to that end, developing effective, inclusive, participative, and coordinated divisions of labor.

Our hybrid leadership council on poverty and inequality would conjoin multiple stakeholders to develop specific implementation schemes to realize SDG targets. Countries that lead the world in terms of overseas development assistance either as a percentage of GDP (e.g., Sweden, Norway, Luxembourg, Denmark, and the Netherlands), or as raw dollar contribution (e.g., the European Union, the USA, and the UK [26]), and countries such as Japan which has funded the majority of the UN Trust Fund for Human Security budget aimed towards building resilience in developing country communities through a variety of methods, may be motivated to translate their donor assistance status into more durable forms of leadership.

To avoid duplicating the concerted efforts now being made to end extreme poverty-defined by the SDGs as living on less than $\$ 1.25 /$ day-our proposed HLC on poverty and inequality aims to focus on the next tier of impoverishment, or the "moderately poor" who live on up to $\$ 3.10 /$ day, according to the World Bank [30]. The principal focus of this HLC is targeted economic and human development-e.g., through micro-financing, vocational skills and entrepreneurship training, animal husbandry, and refining agricultural development techniques to increase food security and ensure sustainable employment and production activities in pastoral communities-to develop sustainable and resilient communities and prevent forced mass economic migration. Poverty is multidimensional, involving not only income growth but also health, nutrition, education, and basic living standards [10, 36], and efforts must be targeted to tackle poverty in all of its forms.

\section{Hybrid leadership council on population}

Every year, the world's population adds 83 million people, which means global population levels could reach over 11 billion by 2100 [16]. This, in addition to lifespan increases and death rate decreases nearly everywhere in the world, has resulted in more people to house, feed, and support in a world of finite resources. This growing population, mostly in the poorest areas of the globe, is perhaps the major hurdle to sustainable development. Despite the fact that global fertility rates have actually declined, other demographic changes require a multi-pronged approach to further dealing with this complex issue.

In 1994, the United Nations held an International Conference on Population and Development ("Cairo Conference"). This was considered a turning point in population-related public policy because the global community shifted from a focus on state exercise of sovereignty-which often results in myopic or repressive population control policies [2] - to recognizing the need to improve people's well-being, which has the effect of decreasing fertility rates. Thus, population policy shifted to a broader focus on social development, reproductive healthcare, ensuring individual rights and empowering women. As with many global conferences in the 1990s, 
many countries made significant changes in policy after Cairo and the global community used the "Cairo Programme" to guide global policy since. However, many of the programmes are underfunded and women's rights (especially women's rights to control their reproductive decisions) remain a divisive issue and has shaped the discussion on today's population policies more than any single issue.

A Population HLC will need to think dynamically about the realities of uneven population growth and development at the global level. Today, global fertility rates actually continue to fall, particularly among Least Developed Countries (LDCs), and this is often attributed to access to reproductive healthcare for women and women's empowerment. People with resources can and will control family size but programs are woefully underfunded and UNFPA says there is a $\$ 700$ million gap in funding for contraceptives for the current 3-year target to reach 120 million women by 2020 [13]. A Resource Action Committee of Population could coordinate global actors (such as the Gates Foundation and United Nations Development Fund) to ensure funding to meet this goal, among others. Another Issue Action Committee could address the realities of declining populations in particular countries (such as Eastern Europe and Japan), where aging populations mean a need for young labor. Coordinated migration policies could alleviate this uneven age gap resulting from low fertility rates. As Africa is expected to account for nearly one half of future population growth by 2050, an IAC could specifically focus on development initiatives on the continent to mediate some of the growth through targeted development projects and better health resources.

\section{Hybrid leadership council on women's inclusion}

A central aspect of any future governance model dedicated to dealing with issues of population, climate change, conflict, and development is the role women play in it. The evidence is overwhelming that when global governance efforts aim to provide women more autonomy and resources, women, states, and the world benefit $[8,19,39]$. This is why the current Sustainable Development Goals and the previous Millennium Development Goals included provisions regarding gender equality and women's health: the effects of women's health clinics, more women in government, and more gender-specific economic resources are all correlated with decreases in population growth, greater state stability, and greater economic growth $[1,21]$.

To expand on modern gains in women's rights, one can look to the success of the global women's rights movement of the late twentieth century for ideas for future governance strategies. In 1975, the UN held its first World Conference on Women, which brought together states and activists in developing a global vision for the advancement of women. Every 5 years through 1995, these conferences were held, which helped coalesce a transnational feminist movement that continues to advance women's rights today. The 1995 conference (commonly referred to as "Beijing" after its site), is considered a critical juncture for women's rights because it helped develop a modern framework-the Platform for Action-that continues to inform global policy efforts aimed at advancing women's rights [11]. Its impact was unprecedented: following this conference, the diffusion of policies to promote more women in government, ensure better economic rights and resources for women, and reduce violence against women were adopted across the globe. States responded to the coordinated activism of women, ushering in a new era that recognizes the importance of placing women and their interests at the center of efforts to improve state governance and stability, economic security, and environmental protection.

However, this coordinated women's rights movement has stalled. The UN conferences were expensive and while the UN held a "Beijing + 20" conference in 2015, its impact fell far short of those of previous conferences. There has also been considerable complacency that the Beijing Platform is "enough," stalling efforts to promote creative thinking on how to promote women's rights and autonomy in such a different world. Since these conferences take years of preparatory meetings at local, regional, and global levels, a Hybrid Leadership Council could resurrect the global conference model on women's rights as a way to reinvigorate policy solutions and activism aimed at addressing gender equality in the twenty-first century.

\section{Conclusion}

The model we have proposed in this paper offers multiple mechanisms to assure accountability and to prevent the emergence of veto players that might stymie action, thus addressing two important concerns, namely, inclusion and efficiency. First, participation is open to all interested actors, thus limiting "gate keepers" to the process. Smaller decision-making groups would be created to streamline decision-making. Since everything the HLCs do will be voluntary, there will be little opportunity for abuse of power. HLC, IAC, RIG, and Assembly member organizations will be those that choose to join. Funders will be those who choose to donate. Projects will be implemented in cooperation and consultation with local and regional actors, both private and governmental. If any government opposes any given project, similar projects can be carried out elsewhere instead. The genesis of these hybrid leadership councils will likely require some policy stimulus. It is worth considering in future research what such stimuli might be in this regard. Fortunately, 
there are institutions arising that could facilitate such stimuli. In particular, the High-Level Political Forum (HLPF) on Sustainable Development at the United Nations and The Global Future Councils of the World Economic Forum could be potential facilitators of such stimuli.

Furthermore, democratic accountability is built into the system of elections of members of the policy-setting HLCs. As noted, regular convocations of the HLC Assemblies would review the actions and plans created by the HLCs and Planning Committees, and amend them as necessary. HLC members would be held accountable through the re-election process. Those HLC members who are not responsive to the expectations of their sectoral peers would not be re-nominated, and those not responsive to the Assembly would not be re-elected. This system of dual accountability should provide a highly effective set of incentives for HLC members.

The main purpose of creating self-organized and informal Hybrid Leadership Councils is to enhance decisionmaking capacity in global governance. Many states are already active in these issue-areas, but mechanisms in existing IGOs to coordinate action among them are often inefficient and slow. HLCs would be relatively nimble because plans could be launched with the consensus of just a small group of committed actors who were elected to the HLC. Multiple mechanisms prevent the emergence of veto players that might stymie action. While some Assembly members, especially in the business sector, may well oppose actions that might be costly to themselves, we expect most Assembly members to be genuinely committed to action. Any HLC member perceived as being obstructive could be replaced at future Assembly meetings. At the same time, the Assembly is not needed to approve action: the Assembly can amend HLC plans, but cannot stop them by creating a disparate coalition of nay-sayers. Plans can be implemented to the extent that positive coalitions can be created to form Issue Action Committees (IACs) and Regional Implementation Groups (RIGs) to carry out initiatives where governments and other key actors are supportive. Sectoral voting in the Assemblies will provide the optimum mix of initiative and practicality to the decision-making process. IGOs and especially NGOs are often marginalized in decision-making for global governance; providing them collectively with half of the voting power in the Assemblies should provide impetus and energy to collective efforts. At the same time, IGOs are accountable to their state members, and states and businesses will be more keenly attuned to the political and economic costs of alternative courses of action-and of course, they will be providing most of the resources. The result should be that while overly idealistic NGO ideas will not be pursued, the hesitations of states and businesses will be challenged, eliciting more energetic action than would be likely without the voting participation of NGOs and IGOs.

Periodic Assembly meetings which feature electing members of HLCs and IACs would offer an additional degree of transparency and community building not only within the relevant community, but also in relation to the global public. Assemblies would be open events, widely described by participants and media. The election process would motivate candidate organizations to justify their election to HLCs and IACs by demonstrating their commitment and effectiveness. The replacement of those member organizations that fail to show such a commitment would increase confidence and trust in those that perform better. Advisory Committees consisting of relevant experts will develop action plans, drawing on the resources and additional expertise of HLC member organizations. These plans are subject to amendment by the full Assembly, and refinement by the IACs. Finally, the RIGs will ensure consultation and participation of local actors and experts in the region of operations so that local peculiarities are considered. Trust development will ultimately be the sustaining feature of such an approach in a future where polarization of political views and suspicion on motives becomes more trenchant. We are conscious that this approach may face opposition in some political quarters where sovereignty and territoriality are still more influential than hard multilateralism. Nevertheless, the process has an incremental mechanism of decision-making that can mitigate such resistance.

\section{Acknowledgements \\ Funding \\ Internal University Support funds \\ Availability of data and materials Not applicable}

The authors gratefully acknowledge the initial motivation for this exercise from the Global Challenges Foundation in Stockholm Sweden.

\section{Authors' contributions \\ The paper was written collectively by the authors through an intensive workshop group-writing process over the course of the semester. All authors read and approved the final manuscript.}

Ethics approval and consent to participate

No ethics approval was required for this manuscript.

Consent for publication

No consent for data usage was needed for this publication.

Competing interests

The authors declare that they have no competing interests.

\section{Publisher's Note}

Springer Nature remains neutral with regard to jurisdictional claims in published maps and institutional affiliations.

\section{Author details}

${ }^{1}$ Department of Political Science, University of Delaware, Newark, DE 19716, USA. ²Department of Geography, University of Delaware, Newark, DE 19716, 
USA. ${ }^{3}$ Professorial Research Fellow, University of Queensland, Brisbane, Australia.

\section{Received: 3 October 2018 Accepted: 16 April 2019}

Published online: 22 May 2019

\section{References}

1. Anderlini, S. (2010). What the women say: participation and UNSCR 1325 Retrieved from MIT Center for International Studies: https://www.usip.org/ sites/default/files/Gender/What_the_Women_Say.pdf

2. Ashford, L. S. (2004). Population Reference Bureau. What was Cairo? The Promise and Reality of ICPD: http://www.prb.org/Publications/Articles/2004/ WhatWasCairoThePromiseandRealityoflCPD.aspx

3. Autesserre S (2010) Peacebuilding, the trouble with the Congo: local violence and the failure of international. Cambridge University Press, Cambridge

4. $\quad$ Ba AD (2018) Governing the safety and security of the Malacca Strait: the Nippon Foundation between the states and the industry. J Contemp Asia 48(2):252-277

5. Bercovitch J (2007) Mediation in international conflicts: theory, practice and developments. In: Zartman WI (ed) Peacemaking in international conflict: methods and techniques. US Institute of Peace, Washington, pp 163-194)

6. Bercovitch J, Derouen K (2004) Mediation in internationalized ethnic conflicts: assessing the determinants of a successful process. Armed Forces Soc 30(2):147-170

7. Breslin S, Nesadurai HE (2018) Who governs and how? Non-state actors and transnational governance in Southeast Asia. J Contemp Asia 48(2):187-203

8. Caprioli M (2003) Gender equality and state aggression. International Interactions, pp 195-214

9. Danjuma MN, Maiwada B, Bindawa AA (2016) Prospects of Farmer Managed Natural Regeneration in Madaroumfa Village, Maradi Department, Republic of Niger. Am J Energy Sci 3(2):1-15

10. Deparment of Economic and Social Affairs (2017) World population prospects: the 2017 revision, United Nations https://esa.un.org/unpd/wpp/ Publications/Files/WPP2017_KeyFindings.pdf

11. Ellerby K (2017) No shortcut to change: an unlikely path to a more genderequitable world. New York University Press, New York

12. Ezeife ND (2014) Projected impact of global warming on West Africa: case for regional and transnational adaptive measures. Ann Surv Int'l \& Comp L 20(1):101-138

13. Forsythe N, Korzeniewicz RP, Durrant V (2000) Gender inequalities and economic growth: a longitudinal evaluation. Econ Dev Cult Chang 48(3):573-617

14. Haglund E, Ndjeunga J, Snook L, Pasternak D (2011) Dry land tree management for improved household livelihoods: farmer managed natural regeneration in Niger. J Environ Manag 92(7):1696-1705

15. Hamilton DS (2014) America's mega-regional trade diplomacy: comparing TPP and TTIP. International Spectator 49(1):81-97

16. Hartmann B (2011) The return of population control: incentives, targets, and the backlash against Cairo

17. Hoffman MJ (2011) Climate governance at the crossroads. Experimenting with a global response after Kyoto. Oxford University Press, New York City

18. Horowitz DL (2001) The deadly ethnic riot. University of California Press, Berkley

19. Kabeer N (2016) Gender equality, economic growth, and women's agency: the 'endless variety' and 'monotonous similarity' of patriarchal constraints. Fem Econ 22(1):295-321

20. Kaufman SJ (2015) Nationalist passions. Cornell University Press, Ithaca

21. Krook ML (2009) Quotas for women in politics. Cambridge University Press, Cambridge

22. Laïdi Z (2014) Towards a post-hegemonic order: the multipolar threat to the multilateral order. Int Polit 51(3):350-365

23. Monks K (2016) Can the Great Green Wall change direction? CNN https:// www.cnn.com/2016/09/22/africa/great-green-wall-sahara/index.html

24. Nesadurai HE (2013) Food security, the palm oil-land conflict nexus, and sustainability: a governance role for a private multi-stakeholder regime like the RSPO? Pac Rev 26(5):505-529

25. Nkonya E, Anderson W (2015) Exploiting provisions of land economics productivity without degrading its natural capital. J Arid Environ 112:33-43

26. OECD (2016) Development aid in 2015 continues to grow despite costs for in-donor refugees. Organisation for Economic Co-operation and
Development http://www.oecd.org/dac/stats/ODA-2015-detailedsummary.pdf

27. Paris R (2014) At war's end: building peace after civil conflict. Cambridge University Press, Cambridge

28. Pettersson T, Wallensteen P (2015) Armed conflicts, 1946-2014. J Peace Res 52(4):536-550

29. Prunier G (1995) The Rwanda Crisis: history of a genocide. Columbia University Press, New York

30. Roser, M., \& Ortiz-Ospina, E. (2017). Global extreme poverty. Our World in Data: https://ourworldindata.org/extreme-poverty/

31. Rummel R (1994) Death by government. Transaction Publishers, New Brunswick

32. Sable CF, Zeitlin J (2008) Learning from difference: the new architecture of experimentalist governance in the European Union. Eur Law J 14(3):271-327

33. Schweller R (2011) Emerging powers in an age of disorder. Glob Gov 17(3):285-297

34. Sendzimir J, Reij CP, Magnuszewski P (2011) Rebuilding resilience in the Sahel: regreening in the Maradi and Zinder regions of Niger. Ecol Soc 16(3): $1-29$

35. Stephen MD (2017) Emerging powers and emerging trends in global governance. Glob Gov 23(3):483-502

36. UN Development Programme (n.d.) Multidimensional poverty index. In: Human development reports http://hdr.undp.org/en/content/ multidimensional-poverty-index-mpi

37. Vestergaard J, Wade RH (2015) Still in the woods: gridlock in the IMF and the World Bank puts multilateralism at risk. Global Pol 6(1):1-12

38. Wolff S, Yakinthou C (2012) Conflict management in divided societies: theory and practice. Routledge, New York

39. World Bank Group (2012) World development report 2012: gender equality and development. World Bank Group https://openknowledge.worldbank. org/handle/10986/4391

40. Zeitlin J (2015) Extending experimentalist governance?: the European Union and transnational regulation. Oxford University Press (OUP), Oxford

\section{Submit your manuscript to a SpringerOpen ${ }^{\circ}$ journal and benefit from:}

- Convenient online submission

- Rigorous peer review

- Open access: articles freely available online

- High visibility within the field

- Retaining the copyright to your article

Submit your next manuscript at $>$ springeropen.com 